\title{
IMPACT OF RESERVOIR HETEROGENEITY ON THE CONTROL OF WATER ENCROACHMENT INTO GAS-CONDENSATE RESERVOIRS DURING $\mathrm{CO}_{2}$ INJECTION
}

\author{
Serhii MATKIVSKYI \\ JSC "Ukrgasvydobuvannya" \\ Oleksandr BURACHOK \\ Ivano-Frankivsk National Technical University of Oil and Gas
}

\begin{abstract}
:
The paper evaluates application of $\mathrm{CO}_{2}$ injection for the control of water encroachment from the aquifer into gascondensate reservoir under active natural water drive. The results of numerical simulations indicated that injection of $\mathrm{CO}_{2}$ at the initial gas-water contact (GWC) level reduces the influx of water into gas-bearing zone and stabilizes the operation of production wells for a longer period. The optimum number of injection wells that leads to the maximum estimated ultimate recovery (EUR) factor was derived based on statistical analysis of the results. The maximum number of injection wells at the moment of $\mathrm{CO}_{2}$ break-through into production wells for homogeneous reservoir is equal to 6.41 (6) and for heterogeneous -7.74 (8) wells. Study results indicated that with the increase of reservoir heterogeneity, denser injection well pattern is needed for the efficient blockage of aquifer water influx in comparison to homogeneous one with the same conditions. Gas EUR factor for the maximum number of injection wells in homogenous model is equal $64.05 \%$ and in heterogeneous $-55.56 \%$. Base depletion case the EURs are $51.72 \%$ and $49.44 \%$, respectively. The study results showed the technological efficiency of $\mathrm{CO}_{2}$ injection into the producing reservoir at initial GWC for the reduction of water influx and improvement of ultimate hydrocarbon recovery.
\end{abstract}

Key words: $3 D$ reservoir model, numerical simulation, enhanced gas recovery (EGR), gas-condensate reservoir, water drive, trapped gas, carbon dioxide $\left(\mathrm{CO}_{2}\right)$ injection

\section{INTRODUCTION}

Rational development of gas-condensate fields under the active water drive is based on systematic control of aquifer water influx into the gas zone and water breakthrough to production wells [1, 2]. Majority of the gas fields are represented by multi-stacked heterogeneous reservoirs [3]. During field development planning stage geological information is limited, and therefore a special attention must be paid to the selection of well locations for maximum drainage of the reservoirs [1]. Non-uniform production well spacing with higher well-count in the crest of the gas-bearing zone is very common. These leads to selective water encroachment into the gas zone through high-permeable rocks and most depleted layers [4]. Selective water invasion causes decrease of gas relative permeability and well productivity due to liquid loading, when mixture velocity in the tubing falls below the critical value of $4-5 \mathrm{~m} / \mathrm{s}$.
With active aquifer water encroachment into gas-bearing layers, production wells are being shut after relatively small cumulative gas production. One of the reasons is the limitation of surface separator and gas treating facilities that are originally not designed to handle huge volumes of water. Water shut-off well treatments and work-overs are usually not effective, since they require a very good understanding of the reasons and paths of water influx. That is why control of edge aquifer water influx is the key task of reservoir management [5].

The majority of gas production in Ukraine is coming from partially or heavily depleted reservoirs with significant remaining volumes of trapped gas. Research of the optimum ways of macro- and micro-trapped gas recovery is an important issue especially with constantly decreasing quality and quantity of the hydrocarbon reserves. [6]. 


\section{RESEARCH OBJECTIVE}

The complexity of remaining hydrocarbon in place recovery under water drive is related to water encroachment from the aquifer into gas-bearing zone and further to production wells. To minimize negative impact of formation water on reservoir development by $\mathrm{CO}_{2}$ injection at initial GWC requires additional research to maximize the ultimate recovery at minimum costs and negative impact on environment.

The objective of the research is to evaluate the influence of heterogeneity on the well pattern density (well spacing and well count) during $\mathrm{CO}_{2}$ injection at the level of initial GWC for the purpose of water encroachment control into the gas-bearing zone using numerical simulation.

The following tasks were solved during the research:

1. Investigation of $\mathrm{CO}_{2}$ injection wells number on the activity of aquifer and control of water encroachment into homogeneous and heterogeneous gas-condensate reservoir.

2. Define the optimum number of $\mathrm{CO}_{2}$ injection wells that leads to the maximum ultimate recovery factor in the presence of active water drive.

\section{LITERATURE REVIEW}

Majority of hydrocarbon reservoirs is associated with active aquifer systems providing influx of water by bottom or edge water drive. Field data indicates that active water drive can produce up to $70-85 \%$ of gas initially in place [7, 8]. Due to the high value of remaining gas in presence of water drive, there is a need in establishment of optimum ways for increase of EUR under such conditions.

Different methods and technologies for gas reservoir management and water encroachment control were already proposed. However, those solutions are normally non-economic and technologically non-feasible since they do not consider reservoir heterogeneity and spatial and vertical variation of petrophysical properties within the reservoir $[9,10]$. In addition to that, there is a necessity to recover macro- and micro-trapped gas due to high demand of gas resources.

Enhanced gas recovery is a very perspective technology that is based on the introduction of additional energy into the reservoir system from the surface. The results of numerous research studies and publications showed high efficiency of non-hydrocarbon gas injection, for example, nitrogen, carbon dioxide, flue gases and their mixtures, etc. $[11,12,13]$.

Methane displacement and gas recovery factor is highly dependent on the type of the injected gas, reservoir heterogeneity and mutual disposition of layers with different permeabilities [14]. Molecular diffusion between two layers of different permeabilities, partially reduces the negative influence of heterogeneity.

$\mathrm{CO}_{2}$ is known to have the best displacing properties in comparison to nitrogen and flue gases [15], resulting in EUR of $81.0-97.4 \%$. Density and viscosity of carbon dioxide under reservoir conditions are significantly higher than those of hydrocarbon gases. High solubility of $\mathrm{CO}_{2}$ in oil, gas-condensate and formation water are additional factors of gas displacement [16]. Results of numerical simulation studies where natural gas was displaced by $\mathrm{CO}_{2}$ are presented in $[17,18,19]$. According to the study [18], gas production until the economic limit followed by $\mathrm{CO}_{2}$ injection leads to higher EUR than in the case when $\mathrm{CO}_{2}$ injection starts from the beginning of reservoir development. $\mathrm{CO}_{2}$ injection at the final stage is the most efficient way to maximize the ultimate gas recovery [19] resulting in EUR of $86 \%$ versus $66 \%$ in case when it was injected from the beginning.

The presented results proved the efficiency of non-hydrocarbon gas injection for EGR but they do not account for technical complexities of final development stage as well as macro-heterogeneity of the reservoirs.

The results of physical and mathematical modeling of natural gas displacement by non-hydrocarbon gases [20, 21, 22] showed high technological efficiency of this EGR method, resulting in higher recoveries and financial indicators based on full-field projects implemented in Ukraine and in other countries $[23,24,25,26,27]$.

The water encroachment and break-through to production wells is important issue for Ukrainian and international gas operators, and therefore, require additional investigation also by means of numerical simulation.

\section{METHODOLOGY OF RESEARCH}

Influence of heterogeneity on water encroachment during carbon dioxide injection into different number of injection wells (well count and spacing) was studied by numerical simulation using Schlumberger software ECLIPSE and Petrel $[28,29]$. Synthetic homogeneous and heterogeneous anticline numerical gas-condensate reservoir models were used in this study (Fig. 1).

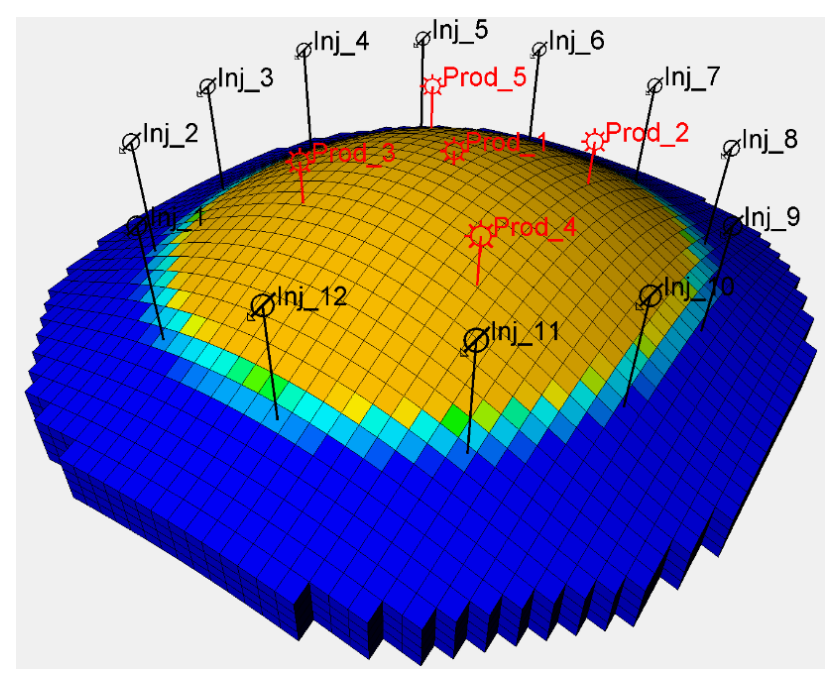

Fig. 1 Conceptual numerical reservoir simulation model showing gas saturation and position of production and injection wells

Simulated gas-condensate reservoir contains $800 \mathrm{mln} . \mathrm{m}^{3}$ of gas in place at initial reservoir pressure of $35 \mathrm{MPa}$, reservoir temperature $358 \mathrm{~K}$, net thickness $15.4 \mathrm{~m}$, effective porosity 0.18 , absolute permeability $8.65 \mathrm{mD}$, initial gas saturation 0.8 
Effective porosity for the layers in heterogeneous model (from top to bottom) are equal $0.17,0.22,0.14$ and 0.18 (Fig. 2), and respective values of absolute permeability $6.55,17.64,3.62$ and 7.99 .

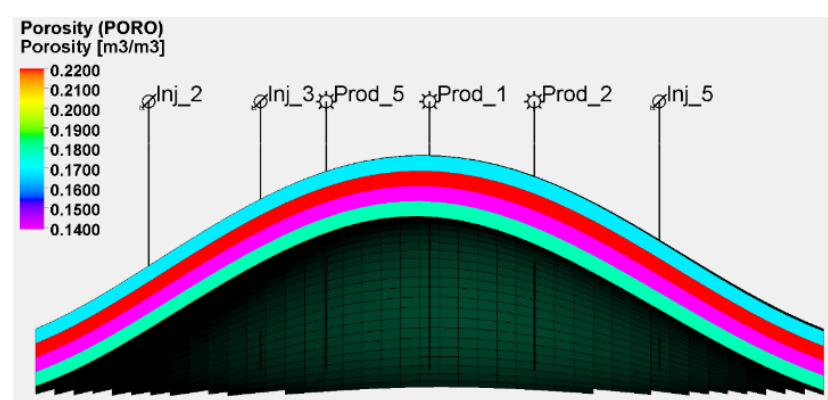

Fig. 2 Porosity distribution in heterogeneous model of gas-condensate reservoir

Duration of $\mathrm{CO}_{2}$ injection into the gas-condensate reservoir at the level of initial GWC was equal 16 months. Production wells were controlled by constant gas rate of $50 \times 10^{3} \mathrm{~m}^{3} / \mathrm{d}$ as well as $\mathrm{CO}_{2}$ injection wells. Production wells are located $400 \mathrm{~m}$ away from each other. Compositional PVT model was used for proper calculation of complex phase behavior during fluid flow and $\mathrm{CO}_{2}$ injection $[30,31,33]$.

$\mathrm{CO}_{2}$ injection was evaluated using different number of injection wells $(4,6,8,12,16)$ equally spaced within the outer boundary of the reservoir. The distance between the injectors for each evaluated case were 1100, 800, 600, $400,300 \mathrm{~m}$ respectively. Production from the reservoir stopped at the moment when carbon dioxide brokethrough into the last production well.

In the case of $\mathrm{CO}_{2}$ injection, the break-through time to each production well was recorded in order to make a proper comparison to depletion case, in which production wells were stopped in exactly same times.

Different number of injection wells leads to different well operation time until the moment of $\mathrm{CO}_{2}$ break-through. Therefore, for each $\mathrm{CO}_{2}$ injection case there was a respective depletion case of different duration of production.

Reservoir production performance was calculated and compared at the moment of $\mathrm{CO}_{2}$ break-through into one of the production wells based on the cumulative water production for the cases with different injection well count.

Graphical method combined with statistical analysis was used for identification of optimum values of the key performance parameters in of results interpretation [32]. Statistical analysis of function parameters $f(x)=a_{0}+a_{1} x$ a chosen in such a way that difference of evaluated points $\left(x_{i} ; y_{i}\right) \mathrm{i}=\overline{1 . . N}$ from the selected trend curve will be minimal. Parameters $a_{0}, a_{1}$ must be such that sum of square root deviations of observed values $y_{i}$ from calculated by a function $f(x)=a_{0}+a_{1} x$ will be minimal. After a few transformations, the system of two linear equations for the regression on unknown parameters was obtained.

$$
\left\{\begin{array}{c}
v, a_{v}\left\{\sigma_{a v}^{2}=\frac{1}{n_{v}-r_{v}} \sum_{i=1}^{n_{v}}\left[f_{v}\left(a_{v}, x_{i}\right)-y_{i}\right] 2\right\}\left\{\hat{v}, \hat{a_{v}}\right\} \\
\varepsilon, a_{\varepsilon}\left\{\begin{array}{c}
\left.\sigma_{a \varepsilon}^{2}=\frac{1}{n_{\varepsilon}-r_{\varepsilon}} \sum_{i=1}^{n_{\varepsilon}}\left[f_{\varepsilon}\left(a_{\varepsilon}, x_{i}\right)-y_{i}\right] 2\right\}\left\{\hat{\varepsilon}, \hat{a_{\varepsilon}}\right\} \\
f_{v}\left(\hat{a}_{v}, x_{*}\right)-f_{\varepsilon}\left(\hat{a}_{\varepsilon}, x_{*}\right)=0 \Rightarrow x_{*}
\end{array}\right.
\end{array}\right.
$$

where:

$\sigma_{a v}^{2}, \sigma_{a \varepsilon}^{2}$-measure of dispersion efficiency $f_{v}$ та $f_{\varepsilon}$ $r_{v}, r_{\varepsilon}$ - number of evaluated parameters in the model $f_{v}\left(a_{v}, x_{\mathrm{i}}\right)$ та $f_{\varepsilon}\left(a_{\varepsilon}, x_{\mathrm{i}}\right)$

Parameters $a_{0}, a_{1}, a_{2}, \ldots, a_{n}$ are selected by solving the above given system of equations. Obtained parameters are used in a function $y=f(x)$ and in such a way the linear equations are obtained for accurate description of calculated values. After that, the plots are built for particular calculated data and approximated each one by straight lines, with the crossing point representing the optimum value.

\section{RESULTS OF RESEARCH}

Using 3D numerical model of gas-condensate reservoir the influence of heterogeneity on aquifer water encroachment during $\mathrm{CO}_{2}$ injection at the level of initial GWC was studied. Based on the results, it was concluded, that the number of injection wells (well spacing) makes a significant impact on reservoir production performance. Dependency between $\mathrm{CO}_{2}$ break-through time into production wells and number of $\mathrm{CO}_{2}$ injectors is shown on Fig. 3.

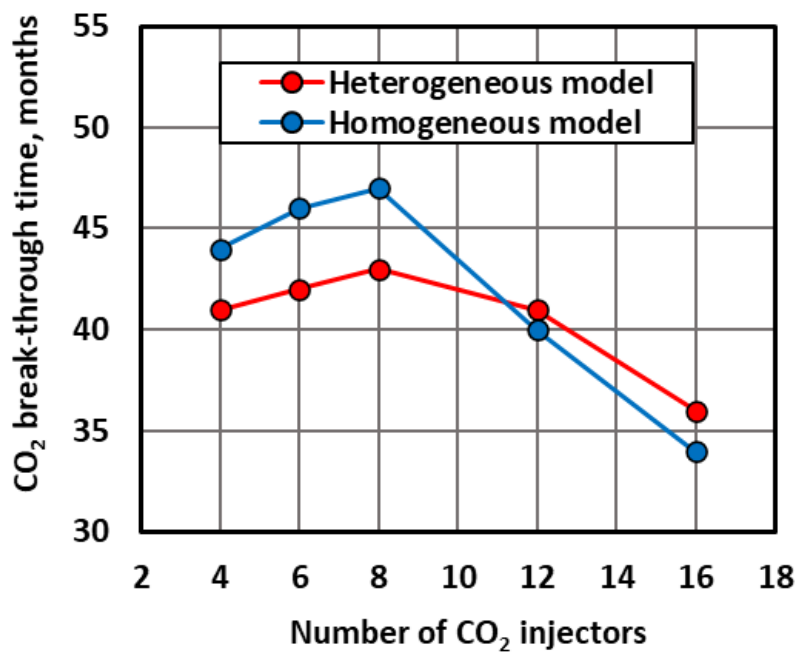

Fig. 3 Dependence of $\mathrm{CO}_{2}$ break-through time from number of injection wells for homogeneous and heterogeneous reservoir

During $\mathrm{CO}_{2}$ injection into homogeneous reservoir model the duration of production well operation depends on number of injection wells (well spacing) and respectively equal for 4 wells -44 months, for 6 wells -46 months, for 8 wells -47 months, for 12 wells -40 months and for 16 wells -34 months. 
In a case of the model with layered heterogeneity the forecasted duration of production time until the moment of $\mathrm{CO}_{2}$ break-through depending on number of injectors: for 4 wells -41 months, for 6 wells -42 months, for 8 wells -43 months, for 12 months -41 months, for 16 wells -36 months.

It is necessary to point out that during $\mathrm{CO}_{2}$ injection, the production period from homogeneous model with minimum number of injectors (4 and 8 ) significantly longer than in the case of heterogeneous model. However, during future increase of the number of injectors the production period of homogeneous reservoir becomes shorter in comparison to heterogeneous.

Analysis of reservoir pressure behavior at the time of $\mathrm{CO}_{2}$ break-through into production wells indicated that increase of injection wells number from 4 to 8 in case of heterogeneous model leads to higher values of reservoir pressure in comparison to homogeneous one. However, the further increase of injectors count is causing the reduction of reservoir pressure in comparison to homogeneous case. Such relationship between reservoir pressure and number of injection wells is due to different production periods until the moment of $\mathrm{CO}_{2}$ break-through. The change of reservoir pressure as a function of injection well count for homogeneous and heterogeneous cases is presented on Fig. 4.

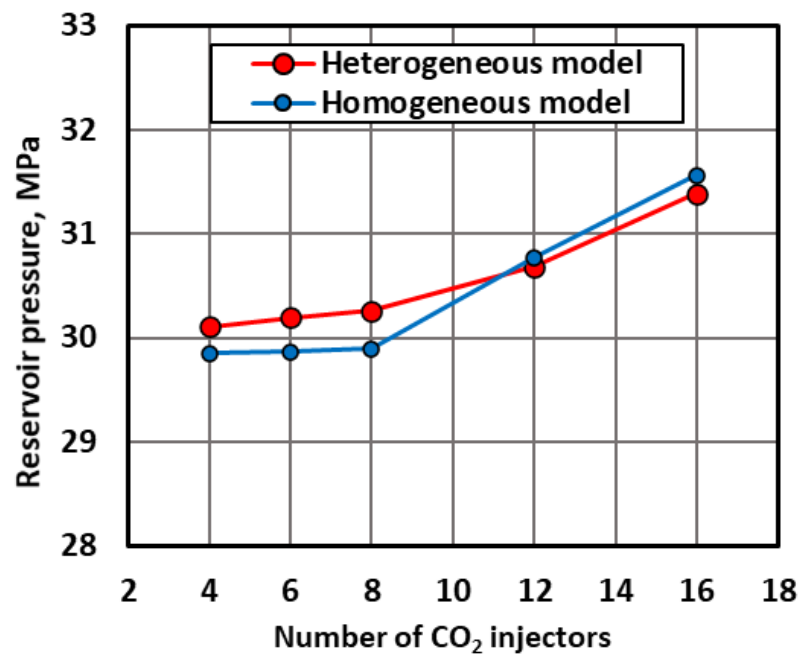

Fig. 4 Change of reservoir pressure at the moment of $\mathrm{CO}_{2}$ breakthrough into production wells for homogeneous and heterogeneous reservoirs as a function of $\mathrm{CO}_{2}$ injection wells number

Looking at the concentrations of carbon dioxide in the reservoir at the moment of $\mathrm{CO}_{2}$ break-through into the first production well of heterogeneous model it is obvious (Fig. 5) that intake capacity is proportional to the permeability of the particular layer. The higher the permeability the faster break-through of injected $\mathrm{CO}_{2}$ is observed in heterogeneous model in comparison to homogeneous one.

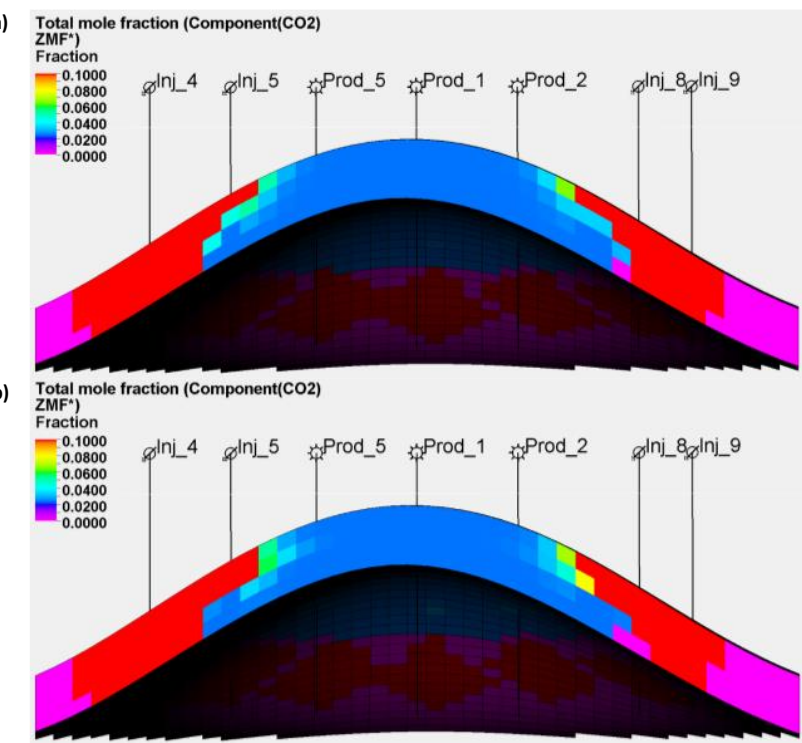

Fig. 5 Carbon dioxide concentration in homogeneous (a) and heterogeneous (b) models at the moment of breakthrough into first production well for the case of 16 injectors

According to the simulation results, cumulative water production is reducing with the increase of number of $\mathrm{CO}_{2}$ injectors in comparison to depletion case. Calculated values of cumulative water production at the moment of $\mathrm{CO}_{2}$ break-through and for the depletion cases are compared in Table 1.

Table 1

Comparison of cumulative water production between depletion and $\mathrm{CO}_{2}$ injection case, at the moment of $\mathrm{CO}_{2}$ break-through as a function of injection wells number

\begin{tabular}{|c|c|c|c|c|}
\hline \multirow{2}{*}{$\begin{array}{c}\text { Number } \\
\text { of injection } \\
\text { wells }\end{array}$} & \multicolumn{3}{|c|}{ Cumulative water production, $\mathbf{m}^{\mathbf{3}}$} \\
\cline { 2 - 5 } & Homogeneous model & \multicolumn{2}{c|}{ Heterogeneous model } \\
\hline 4 & 99.47 & 19.93 & 5.93 & 0.32 \\
\hline 6 & 561.38 & 98.07 & 12.58 & 0.34 \\
\hline 8 & 2304.04 & 298.12 & 137.45 & 0.41 \\
\hline 12 & 0.47 & 0.07 & 1.62 & 0.06 \\
\hline 16 & 0.06 & 0.03 & 0.06 & 0.03 \\
\hline
\end{tabular}

We also calculated the ultimate gas recovery factor for both injection cases at the moment of $\mathrm{CO}_{2}$ break-through and for the respective depletion cases both for homogeneous and heterogeneous models (Table 2).

Table 2 Comparison of gas ultimate recovery factors between depletion and $\mathrm{CO}_{2}$ injection case, at the moment of $\mathrm{CO}_{2}$ break-through as a function of injection wells number

\begin{tabular}{|c|c|c|c|c|}
\hline \multirow{2}{*}{$\begin{array}{c}\text { Number } \\
\text { of injection wells }\end{array}$} & \multicolumn{3}{|c|}{$\begin{array}{c}\text { Ultimate gas recovery factor, frac. } \\
\text { Homoneous } \\
\text { model }\end{array}$} & \multicolumn{2}{c|}{$\begin{array}{c}\text { Heterogeneous } \\
\text { model }\end{array}$} \\
\cline { 2 - 5 } & Depletion & Injection & Depletion & Injection \\
\hline 4 & 40.01 & 41.48 & 36.71 & 39.30 \\
\hline 6 & 41.33 & 43.24 & 37.21 & 40.38 \\
\hline 8 & 42.46 & 43.37 & 37.50 & 41.15 \\
\hline 12 & 33.61 & 37.83 & 33.77 & 38.61 \\
\hline 16 & 19.03 & 32.27 & 22.11 & 34.13 \\
\hline
\end{tabular}


In case of homogeneous reservoir, increasing the injection wells number from 4 to 8 results in maximum EUR of gas equal to $43.37 \%$ at the moment of $\mathrm{CO}_{2}$ break-through, but with further increase of the injector count quickly reduces the gas recovery due to very fast break-through of $\mathrm{CO}_{2}$. During the carbon dioxide injection into heterogeneous reservoir, the maximum gas recovery of $41.15 \%$ is achieved with 8 injection wells. Further increase of the injection wells number to 16 leads to decrease of gas recovery towards $34.13 \%$. The respective plots for the change of gas recover factor with the number of wells for homogeneous and heterogeneous models are shown on Fig. 6.

a)

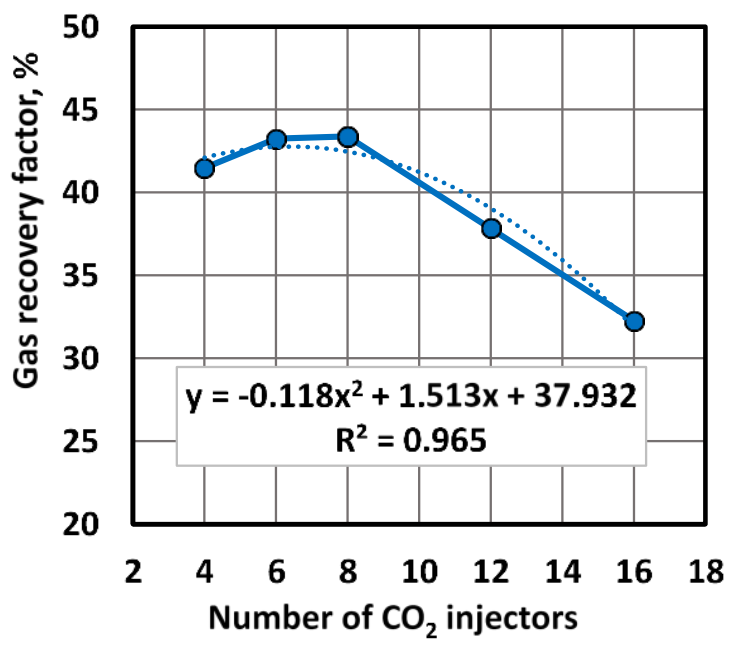

b)

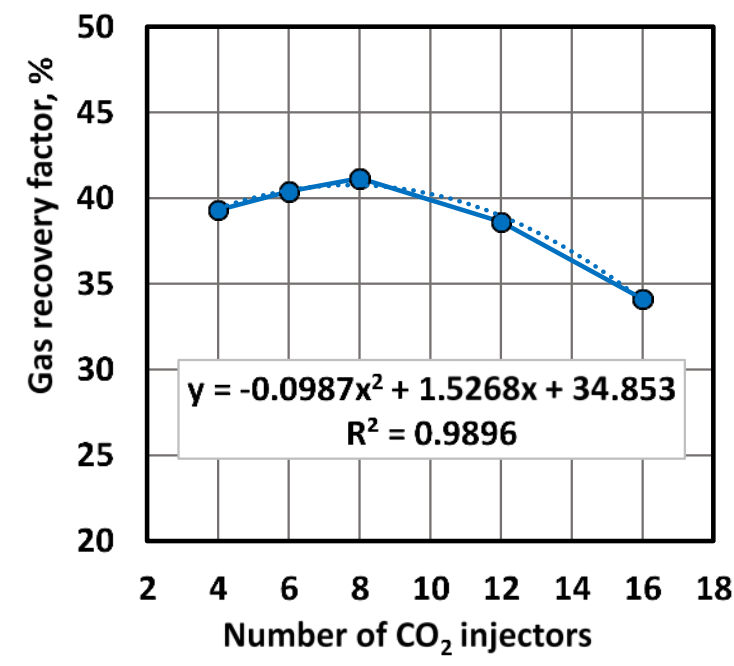

Fig. 6 Gas recovery factor at the moment of $\mathrm{CO}_{2}$ breakthrough into production wells for homogeneous ( $a$ ) and heterogeneous (b) reservoirs as a function of $\mathrm{CO}_{2}$ injection wells number

Based on the statistical results analysis, the necessary number of injection wells for the efficient blockage of aquifer water encroachment was defined. At the moment of $\mathrm{CO}_{2}$ break-through the maximums number of injection wells is equal to $6.41(6)$ for homogeneous reservoir and 7.74 (8) for heterogeneous gas-condensate reservoir. The forecasted gas recovery factor for the stated above optimum number of injection wells for homogeneous reservoir is equal to $64.05 \%$ and $55.65 \%$ for heterogeneous one.

\section{DISCUSSION}

Evaluation of the efficiency of $\mathrm{CO}_{2}$ injection into gas-condensate reservoir at the level of initial GWC for the control of aquifer water encroachment into gas zone was performed with help of numerical simulation software from Schlumberger - ECLIPSE and Petrel. Results analysis of the development indicators for homogeneous and heterogeneous reservoirs allowed establishment of the key dependencies.

Simulation results showed that presence of layered reservoir heterogeneity requires higher number of injection wells (smaller well number) for efficient blockage of water encroachment from the aquifer in comparison to homogeneous reservoir. This is due to the presence of high-permeable layers that serve as a flow passage for water and injected $\mathrm{CO}_{2}$. It is also confirmed by calculations of period of production until the $\mathrm{CO}_{2}$ break-through to production wells when 4, 6 and 8 injection wells were used. The further increase of the number of injection wells from 8 to 16 in the case of heterogeneous reservoir increases the operational period of heterogeneous reservoir in comparison to homogeneous. This is caused by the blockage of water within the greater area and volume of high-permeable layers by $\mathrm{CO}_{2}$ injection proving the high efficiency of the proposed method of $\mathrm{CO}_{2}$ injection at the initial level of GWC.

\section{CONCLUSIONS}

1. Effect of $\mathrm{CO}_{2}$ injection wells number during injection at the level of initial GWC on the activity of aquifer system was studied with help of numerical simulation. Homogeneous and heterogeneous gas-condensate reservoir cases were evaluated.

The simulation results showed that increase of well count (reduction of well spacing) provides the decrease of aquifer water production in both homogeneous and heterogeneous models in comparison to depletion cases. $\mathrm{CO}_{2}$ injection well count increase improves the spatial distribution of $\mathrm{CO}_{2}$, creating a better barrier against water encroachment. The method application enables efficient water movement control from the aquifer into the gasbearing zone.

2. Statistical result analysis derived the optimum number of injection wells for $\mathrm{CO}_{2}$ injection at the level of initial GWC for control of water encroachment from the aquifer into the gas-bearing zone. The optimum number of $\mathrm{CO}_{2}$ injectors for homogeneous reservoir is equal to 6 and for heterogeneous -8 wells.

In case of high level of layer heterogeneity in the reservoir the higher number (smaller well spacing) is needed for efficient blockage of aquifer water encroachment in comparison to homogeneous reservoir with the same conditions.

The gas ultimate recovery factor for optimum number of injection wells in homogeneous model is equal $64.05 \%$ and in heterogeneous model $-55.56 \%$. 


\section{REFERENCES}

[1] V.S. Boyko, R.M. Kondrat, R.S. Yaremiychuk. Dovidnyk z naftohazovoyi spravy, Kyiv: Lviv, 1996, 620 pp. (In Ukrainian).

[2] S.V. Matkivskyy, S.O. Kovalchuk, O.V. Burachok, O.R. Kondrat, L.I. Khaydarova. "Doslidzhennya vplyvu neznachnoho proyavu vodonapirnoyi systemy na dostovirnist' material'noho balansu kolektoriv". Rozvidka ta rozrobka naftovykh i hazovykh rodovyshch, №2 (75), 2020, pp. 43-51. https://doi.org/10.31471/1993-99732020-2(75)-43-51 (In Ukrainian).

[3] A. Romi, O. Burachok, M.L. Nistor, C. Spyrou, Y. Seilov, O. Djuraev, S. Matkivskyi, D. Grytsai, O. Goryacheva, R. Soyma. "Advantage of Stochastic Facies Distribution Modeling for History Matching of Multi-stacked Highly-heterogeneous Field of Dnieper-Donetsk Basin", presented at Fourth EAGE Conference on Petroleum Geostatistics, Florence, Italy, 2019, https://doi.org/10.3997/22144609.201902188

[4] S. Matkivskyi, O. Kondrat, O. Burachok. "Investigation of the influence of the carbon dioxide $\left(\mathrm{CO}_{2}\right)$ injection rate on the activity of the water pressure system during gas condensate fields development", presented at Global Trends, Challenges and Horizons, Dnipro, Ukraine, 2020. https://doi.org/10.1051/e3sconf/202123001011

[5] V.S. Boyko, R.V. Boyko, L.M. Keba, O.V. Semins'kyy. Obvodnennya hazovykh i naftovykh sverdlovyn. Kyiv: Mizhnarodna ekonomichna fundatsiya, 2006, 791 pp. (In Ukrainian).

[6] R.M. Kondrat, V.M. Doroshenko, O.R. Kondrat. "Osoblyvosti zavershal'noyi stadiyi rozrobky rodovyshch nafty i hazu", Naftohazova enerhetyka, № 1, 2007, pp. 1721. http://elar.nung.edu.ua/handle/123456789/1303. (In Ukrainian)

[7] R.M. Kondrat. Hazokondensatootdacha plastov. Moscow: Nedra, 1992, 255 pp. (In Russian).

[8] A. Firoozabadi, G. Olsen, V.T. Golf-Racht. "Residual Gas Saturation in Water-Drive Gas Reservoir", SPE paper 16335 presented at SPE California Regional Meeting, Ventura, California, USA, 1987. https://doi.org/10.2118/16355-MS

[9] S.N. Zakirov. Razrabotka gazovykh, gazokondensatnykh i neftegazokondensatnykh mestorozhdeniy. Moscow: Struna, 1998, 628 pp. (In Russian).

[10] S. N. Zakirov. Teoriya i proyektirovaniye razrabotki gazovykh i gazokondensatnykh mestorozhdeniy: uchebn. pos. dlya vuzov, Moscow: Nedra, 1980, 334 pp. (In Russian).

[11] R.M. Kondrat and L.I. Khaidarova. "Enhanced gas recovery from depleted gas fields with residual natural gas displacement by nitrogen", Naukovyy visnyk Natsional'noho hirnychoho universytetu, № 5, 2017, pp. 23-28. http://nbuv.gov.ua/UJRN/Nvngu_2017_5_6 (In Ukrainian).

[12] D.D. Mamora and J.G. Seo. "Enhanced Gas Recovery by Carbon Dioxide Sequestration in Depleted Gas Reservoirs", SPE paper 77347 presented at SPE Technical Conference and Exhibition, San Antonio, Texas, USA, 2002. https://doi.org/10.2118/77347-MS

[13] O. Kondrat and S. Matkivskyi. "Research of the influence of the pattern arrangement of injection wells on the gas recovery factor when injecting carbon dioxide into reservoir". Technology and system of power supply, №5/1 (55), 2020, pp. 12-17. https://doi.org/10.15587/27065448.2020 .215074
[14] A.T. Turta, S.S.K. Sim, A.K. Singhal, B.F. Hawkins. "Enhanced Gas Recovery: Effect of Reservoir Heterogeneity on Gas-Gas Displacement", Presented at Canadian International Petroleum Conference, Calgary, Alberta, Canada, 2009. https://doi.org/10.2118/2009-023

[15] J.P. Clancy and R.E. Gilchrist. "Nitrogen injection Applications Emerge in the Rockies". SPE paper 11848 presented at SPE Rocky Mountain Regional Meeting, Salt Lake City, Utah, USA, 1983. https://doi.org/10.2118/11848-MS

[16] S.S.K. Sim, A.T. Turta, A.K. Singhal, B.F. Hawkins. "Enhanced Gas Recovery: Factors Affecting Gas-Gas Displacement Efficiency", presented at 9th Canadian International Petroleum Conference, Calgary, Canada, 2008. https://doi.org/10.2118/2008-145

[17] M.M. Rafiee, M. Ramazanian. "Simulation Study of Enhanced Gas Recovery Process Using a Compositional and a Black Oil Simulator". SPE paper 144951 presented at SPE Enhanced Oil Recovery Conference, Kuala Lumpur, Malaysia, 2011. https://doi.org/10.2118/144951-MS

[18] S.A. Jikich, D.H. Smith, W.N. Sams, G.S. Bromhal. "Enhanced Gas Recovery (EGR) with Carbon Dioxide Sequestration: A Simulation Study of Effects of Injection Strategy and Operational Parameters". SPE paper 84813 presented at SPE Eastern Regional Meeting, Pittsburgh, Pennsylvania, 2003. https://doi.org/10.2118/84813-MS

[19] A. Al-Hasami, S. Ren, B. Tohidi. "CO2 Injection for Enhanced Gas Recovery and Geo-Storage: Reservoir Simulation and Economics". SPE paper 94128 presented at SPE Europec/EAGE Annual Conference, Madrid, Spain, 2005. https://doi.org/10.2118/94129-MS

[20] C. M. Oldenburg, D. H. Law, Y. L. Gallo, S. P. White. "Mixing of $\mathrm{CO}_{2}$ and $\mathrm{CH}_{4}$ in Gas Reservoirs: Code Comparison Studies", Proceedings of the 6th International Conference on Greenhouse Gas Control Technologies, Volume 1, 2003, pp. 443-448. https://doi.org/10.1016/B978-0080442761/50071-4.

[21] A.T. Turta, S.S.K. Sim, A. K. Singhai, B. F. Hawkins "Basic Investigations on Enhanced Recovery by Gas-Gas Displacement". Journal of Canada Petroleum Technology. Volume 47, Number 10, 2008. https://doi.org/10.2118/08-10-39

[22] S. Kryvulya, S. Matkivskyi, O. Kondrat, Ye. Bikman. "Approval of the technology of carbon dioxide injection into the V-16 water driven reservoir of the Hadiach field (Ukraine) under the conditions of the water pressure mode". Technology and system of power supply. №6/1(56), $2020 . \quad$ pp. 13-18. https://doi.org/10.15587/2706-5448.2020.217780 (In Ukrainian).

[23] Ye.M. Bakulin. "Osnovni napryamky rozvytku naftovoyi i hazovoyi promyslovosti Ukrayiny". Rozvidka ta rozrobka naftovykh i hazovykh rodovyshch, № 4(25), 2010, pp. 5-13. (In Ukrainian).

[24] R.M. Ter-Sarkisov. Razrabotka i dobycha trudnoizvlekayemykh zapasov uglevodorodov. Moscow: Nedra, 2005, 407 pp. (In Russian).

[25] Q.M. Malik and M.R. Islam. " $\mathrm{CO}_{2}$ Injection in the Weyburn Field of Canada: Optimization of Enhanced Oil Recovery and Greenhouse Gas Storage With Horizontal Wells", SPE paper 59327 presented at the 2000 SPE/DOE Improved Oil Recovery Symposium, Tulsa, Oklahoma, 2000. https://doi.org/10.2118/00-09-01 
[26] S. Doleschall, A. Szittar, G. Udvardi. "Review of the 30 Years' Experience of the CO2 Imported Oil Recovery Projects in Hungary". SPE paper 22362 presented at International Meeting on Petroleum Engineering, Beijing, China, 1992. https://doi.org/10.2118/22362-MS

[27] H. Agustssen and G.H. Grinestaff. "A Study of IOR by $\mathrm{CO}_{2}$ Injection in the Gullfaks Field, Offshore Norway", SPE paper 89338 presented at SPE/DOE 14th Symposium on Improved Oil Recovery, Tulsa, Oklahoma, USA, 2004. https://doi.org/10.2118/89338-MS

[28] ECLIPSE* Technical Description. Version 2020.1 (c) Schlumberger, 2020, pp. 1078. *Mark of Schlumberger.

[29] Petrel* Help. Version 2019.2. *Mark of Schlumberger.

[30] O.V. Burachok, D.V. Pershyn, S.V. Matkivskyy, Ye.S. Bikman, O.R. Kondrat. "Osoblyvosti vidtvorennya rivnyannya stanu hazokondensatnykh sumishey za umovy obmezhenoyi vkhidnoyi informatsiyi", Rozvidka ta rozrobka naftovykh i hazovykh rodovyshch, № 1(74), 2020, pp. 82-88. https://doi.org/10.31471/1993-9973-2020$1(74)-82-88$

\section{Serhii Matkivskyi}

ORCID ID: 0000-0002-4139-1381

JSC "Ukrgasvydobuvannya"

Department of analysis and 3D modeling of hydrocarbon field

Kudriavska Street, 26/28, 04053, Kyiv, Ukraine

e-mail: matkivskij@gmail.com

\section{Oleksandr Burachok}

ORCID ID: 0000-0001-9935-3970

Ivano-Frankivsk National Technical University

of Oil and Gas

Karpatska St., 15, 76019, Ivano-Frankivsk, Ukraine

e-mail: oburachok@googlemail.com
[31] C.H. Whitson and M.R. Brule. Phase Behavior, Richardson, Texas, 2000, 240 pp. (SPE Monograph Series, Volume 20).

[32] M.A. Myslyuk and Yu.O. Zarubin. Modelyuvannya yavyshch i protsesiv u naftohazopromysloviy spravi: pidruchnyk. Ivano-Frankivsk: Ekor, 1999, 494 pp. (In Ukrainian).

[33] O. Burachok, D. Pershyn, C. Spyrou, G. Turkarslan, M.L. Nistor, D. Grytsai, S. Matkivskyi, Y. Bikman, O. Kondrat. "GasCondensate PVT Fluid Modeling Methodology Based on Limited Data", presented at $82^{\text {nd }}$ EAGE Conference \& Exhibition, Amsterdam, The Netherlands, 2020. https://doi.org/10.3997/2214-4609.202010155 